American Journal of Applied Sciences 8 (4): 303-309, 2011

ISSN 1546-9239

(C) 2010 Science Publications

\title{
Synthesis and Calcium Channel Blocking Activity of 1, 4-Dihydropyridine Derivatives Containing Ester Substitute and Phenyl Carbamoyl Group
}

\author{
${ }^{1}$ Bassem Sadek, ${ }^{1}$ Khairi Mustafa Salem Fahelelbom, \\ ${ }^{2}$ Laurentiu Morusciag and ${ }^{3}$ Sigurd Elz \\ ${ }^{1}$ Department of Pharmaceutical Sciences, \\ College of Pharmacy, Al-Ain University of Science and Technology, \\ P.O. Box 64141, Al Ain, United Arab Emirates \\ ${ }^{2}$ Department of Pharmaceutical Chemistry, \\ Faculty of Pharmacy, \\ Carol Davila" University of Medicine and Pharmacy, \\ Traian Vuia 6, Sect. 2, 020956, Bucharest, Romania \\ ${ }^{3}$ Department of Pharmaceutical/Medicinal Chemistry, \\ Faculty of Chemistry and Pharmacy, \\ University of Regensburg, University Str. 31, D-93053 Regensburg, Germany
}

\begin{abstract}
Problem statement: Several studies on the synthesis of new nifedipine analogs have been carried out, but the literature reveled that no study on the synthesis and calcium channel blocking activity of the substituted ester with an amide (5-phenylcarbamoyl) moiety has been reported. Approach: Six new derivatives of m-nifedipine have been successfully synthesized by substituting an ester moiety with an amide (5-phenylcarbamoyl) moiety, using a modified Hantzsch reactions and tested for their pharmacological activities. The nifedipine analogs 1-6 were characterized and confirmed using elemental analysis, Infrared spectroscopy (IR), Nuclear Magnetic Resonance ( ${ }^{1} \mathrm{H}$ NMR) and Mass spectroscopy. The purity of the compounds was ascertained by melting point and TLC. The in vitro calcium channel blocking activities were evaluated using the high $\mathrm{K}^{+}$concentration of Porcine Coronary Artery Smooth Muscles (PCASM) assay. Results: The compounds (1-2) failed to exhibit any blocking activity (IC50 $=10^{-7}$ to $10^{-5}$ $\mathrm{M}$ range), while the compounds 3-6 relaxed precontracted porcine coronary artery smooth muscles with pEC50 values ranging between $4.37 \pm 0.10$ (compound 3) and 6.46 \pm 0.07 (compound 5), indicating that compounds 3-6 exhibit comparable potencies in blocking calcium channels to reference drug varapamil $(6.97 \pm 0.15)$ and m-nifedipine (6.48 \pm 0.05$)$. Conclusion: The results of this study showed that some of the developed new compounds possess maximal calcium channel blocking effects comparable to m-nifedipine. The developed compounds in the present study will predicatively show an increased metabolic stability and consequently longer duration of actions compared to m-nifedipine and could be, therefore, suitable candidates for further optimization to be evaluated as a new class of antihypertensive drugs.
\end{abstract}

Key words: 4-Dihydropyridine Derivatives, phenyl carbamoyl group, m-nifedipine, antihypertensive activity, Krebs-Henseleit Solution (KHS), Pentylenetetrazole (PTZ), Porcine Coronary Artery Smooth Muscles (PCASM), calcium channel, antihypertensive drugs, isolated cardiac, pressure-induced seizures, pharmacological observations

\section{INTRODUCTION}

1,4-Dihydropyridine calcium channel blockers $(1,4-$ DHPs) are an important class of drugs which induce relaxation of vascular smooth muscle, preferentially in arteries and display a negative inotropic effect on isolated cardiac muscle via binding to a high affinity binding site in 2-type voltage-dependent $\mathrm{Ca}^{2+}$ channel (Poole-Wilson et al., 2006; 1977; Richard, 2005). In therapy, this class of drugs has been used in general medical practice worldwide for the treatment of hypertension and vasospastic angina for over 3 decades (Richard, 2005).

Corresponding Author: Bassem Sadek, Department of Pharmaceutical Sciences, College of Pharmacy,

Al-Ain University of Science and Technology, P.O. Box 64141, Al Ain,

United Arab Emirates Tel.: +97137611185 Fax: +97137611198 
Furthermore, there are considerable evidences that calcium is an important factor for the induction of epilepsy. Specifically, different seizure-inducing agents or procedures cause a rapid intraneuronal influx of calcium ions, which is causally related to the subsequent epileptiform activity (Richard, 2005; Beig et al., 2009; Otoom and Hasan, 2006; Samzadeh-Kermani et al., 2009). Conversely, calcium channel blockers have proven to be effective against the whole range of convulsive procedures including electro and Pentylenetetrazole (PTZ) convulsions (Ghasemi et al., 2010; Shafiee et al., 2004) and sound and high pressure-induced seizures (NGouemo et al., 2010; Luszczki et al., 2008). Previous quantitative structureactivity relationship studies of asymmetric derivatives indicated that the vasodilative as well as the anticonvulsant potency of 1,4-DHPs was dependent upon lipophilic character of the aliphatic substituents located at 3-,4- and 5-position of 1,4-DHPs skeleton (Khoshneviszadeh et al., 2009; Miri et al., 2009).

In light of the previous pharmacological observations and therapeutic importance of 1,4-DHP class, it appeared of interest to design and synthesize new derivatives of $m$ nifedipine in which for the first time a methyl ester is substituted by 5-phenylcarbamoyl at 5-position of 1,4DHP ring system. The aim of such aromatic substitution was undertaken to evaluate the influence of such replacement on calcium channel blocking activity.

\section{METERIALS AND METHODS}

Materials: All reagents were of analytical grades and were used as received without further purification. Most of the compounds were obtained from the following companies; Merck, Germany, Sigma-Aldrich, USA) and all aqueous solutions were prepared with double distilled water (DD-water).

Instruments: NMR spectra were recorded with a Bruker Avance $300 \mathrm{MHz}$ spectrometer at $300 \mathrm{~K}$, using TMS as an internal standard and chloroform-d1 as a solvent (Germany). IR spectra ( $\mathrm{KBr}$ or pure solid) were measured with a Bruker Tensor 27 spectrometer (Germany). Melting points were determined with a Buechi B-545 (Romania). MS spectra were measured with a Finnigan MAT 95 (EI, $70 \mathrm{eV}$ ) or with a Finnigan Thermo Quest TSQ-7000 (ESI) (DCM/MeOH +10 $\mathrm{mmol} / \mathrm{L} \quad \mathrm{NH}_{4} \mathrm{Ac}$ ), respectively (Germany). Elemental analyses were performed by the Analytical Laboratory of the University of Regensburg. All reactions were carried out under nitrogen. Chemical structures and names were created using ChemDraw Ultra 10.0 software.

\section{Chemical synthesis:}

Synthesis of methylacetoacetic ester a: A stirring solution of methanol $(50 \mathrm{mmol})$ and 2,2,6-trimethyl$4 H-1,3$ dixine-4-one $(7.1 \mathrm{~g}, 50 \mathrm{mmol})$ in $10 \mathrm{~mL}$ xylene was refluxed for $30 \mathrm{~min}$. The reaction mixture was cooled, the xylene was removed and distillation of the mixture afforded methlacetoacetic ester which was used immediately in subsequent reaction to synthesize $b$.

Synthesis of methyl-3-aminocrotonate b: A solution of methylacetoacetate $(4 \mathrm{mmol})$ and ammonium acetate $(6$ mmol) in $5 \mathrm{ml}$ ethanol was refluxed for $24 \mathrm{~h}$. After cooling the mixture, ethanol was removed and the resulting precipitate, methyl-3-aminocrotonate $\mathrm{b}$ is a white substance, $\mathrm{mp} 82-83^{\circ} \mathrm{C}$, yield $67 \%$. Then, $\mathrm{b}$ was immediately used in following subsequent reactions.

Synthesis of bezylidene-3-oxo-N-phenylbutanamides c1-c6: A stirring solution of corresponding substituted benzaldehyde derivative $(2 \mathrm{mmol})$, correspondong substituted N-phenyl acetoacetamide derivative (2 $\mathrm{mmol})$ and dry benzene $(5 \mathrm{ml})$ was refluxed for $7 \mathrm{~h}$, during which the resultant water was removed via Dean-Stark trap. After cooling, the benzene was removed and the residues were purified on silica-gel with chloroform-methanol-ethylacetate (92/4/4), to give pure compounds c1-c6.

Synthesis of 5-(phenylcarbamoyl) 2, 6-dimethyl-4-(3nitro (chloro) phenyl) 1, 4-dihydropyridine-3carboxylate derivatives 1-6: A stirring solution of methyl 3-aminocrotonate $\mathrm{b}(1.2 \mathrm{mmol})$ and compounds c1-c6 $(1.2 \mathrm{mmol})$ in $5 \mathrm{ml}$ 2-propanol was refluxed for 24h. After cooling, the solution was conentrated under reduced pressure and purified by recrystallization from a suitable solvent to give pure compounds 1-6.

Schematic diagrams 1-3 of the Synthesis 5(phenylcarbamoyl)2,6-dimethyl-4-(2nitro(chloro)phenyl)1,4-dihydropyridine-3carboxylate derivatives (1-6): The synthetic route of the 1,4-DHP derivatives 1-6 was achieved following four stages outlined in Fig. 1-3. The first stage and second stage comprised the reaction of methanol with 2, 2, 6-trimethyl-4H-1, 3-dioxin-one to afford methylacetoacetic ester a (Cheung et al., 2010), which was converted into methy-3-aminocrotonate $b$ through reaction with ammonium acetate Fig. 1. The third stage was accomplished by a reaction of corresponding substituted benzaldehydes with $\mathrm{N}$ phenyl acetoacetamide leading to the corresponding intermediates c1-c6 Fig. 2 (Cheung et al., 2010). 
Am. J. Applied Sci., 8 (4): 303-309, 2011

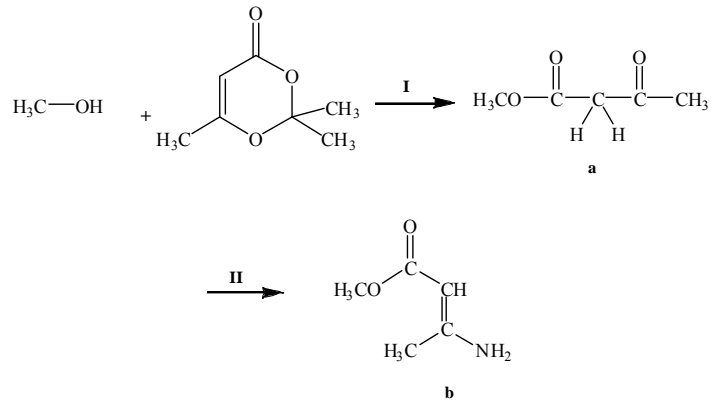

Fig. 1: The synthesis of methy-3-aminocrotonate $b$

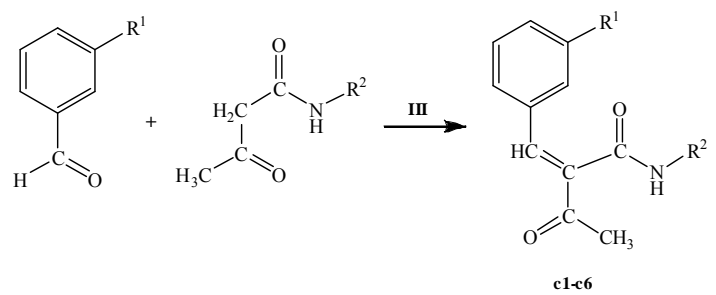

Fig. 2: The synthesis of corresponding intermediates $\mathrm{c} 1-\mathrm{c} 6$
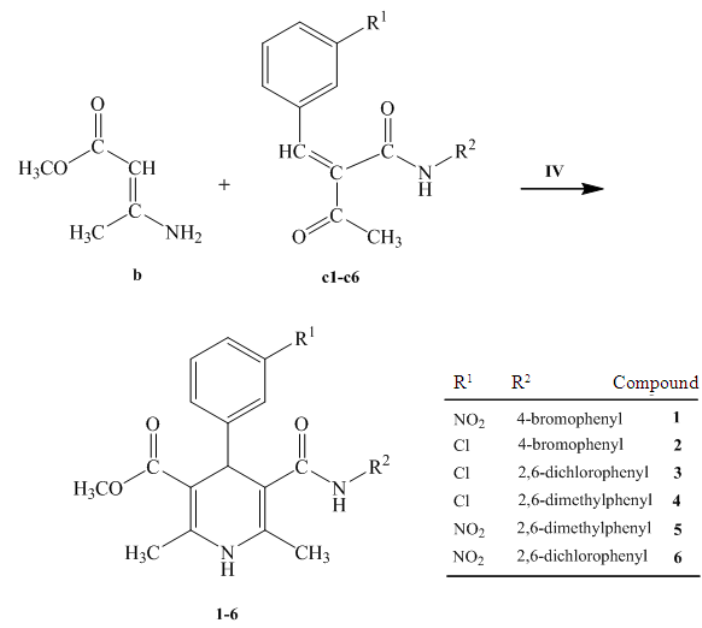

Fig. 3: The synthesis of titled compounds 1-6

In the fourth stage, titled compounds 1-6 were synthesized by a modified Hanstzch reaction, using a procedure reported by Cheung et al. (2010) (53.773.3\% yield) Fig. 3 (Cheung et al., 2010).

\section{Pharmacological activity:}

Pharmacology investigations on porcine coronary artery:

Method of Isolated tissue bath: Porcine hearts were obtained from the local slaughterhouse and placed in ice cold oxygenated modified Krebs-Henseleit Solution
(KHS) of the following composition (mM): $\mathrm{NaCl} 118$, $\mathrm{KCl}$ 4.7, $\mathrm{CaCl}_{2}$ 1.6, $\mathrm{MgSO}_{4} 1.2, \mathrm{KH}_{2} \mathrm{PO}_{4} 1.2, \mathrm{NaHCO}_{3}$ 25 and D-glucose $11(\mathrm{pH}$ 7.4). The left anterior descending coronary artery (Ramus interventricularis anterior) and the right coronary artery (A. coronaria dextra) were dissected from the hearts, cleaned of fat and adhering tissue and cut into rings (approximately 2$3 \mathrm{~mm}$ outer diameter and 3-4 $\mathrm{mm}$ in length). Rings were mounted between two stainless steel hooks, placed in 20-ml water-jacketed organ chambers and constantly exposed to oxygenated modified KHS $\left(\mathrm{O}_{2} / \mathrm{CO}_{2}, 95: 5 \%\right.$; $\mathrm{pH} 7.4 ; 37^{\circ} \mathrm{C}$ ). Tissues were equilibrated for $60 \mathrm{~min}$ under a resting tension of $2.0 \mathrm{~g}$ with buffer replacement after $30 \mathrm{~min}$. Isometric force was measured with FMI TIM-1020 isometric force transducers connected to a TSE 4711 transducer coupler and a Siemens C 1016 compensograph. During a period of $200 \mathrm{~min}$, tissues were stimulated three times with $\mathrm{KCl}(30 \mathrm{mM})$ with 5 and 3-min washing periods between each challenge. The presence or absence of endothelium was assessed functionally by measuring the extent of endotheliumdependent relaxation following application of substance $\mathrm{P}(10 \mathrm{nM})$ after the third $\mathrm{KCl}$ challenge. To inhibit vascular eicosanoid production by cyclooxygenase, experiments were performed in the continuous presence of indomethacin $(6 \mu \mathrm{M})$ (Moritz et al., 2006).

Compounds: Compounds were dissolved in deionized water (verapamil) or ethanol (1-6) to a $100 \mathrm{mmol} / \mathrm{L}$ stock solution. Stock solutions were diluted in deionized water with the exception of 1-6 of which 10 $\mathrm{mmol} / \mathrm{L}$ solutions were prepared in ethanol. Final organ bath concentrations of ethanol did not exceed $0.54 \%$. Experiments with vehicle were run in parallel. Vehicle showed no relaxant response.

Data analysis: Data are presented as a mean \pm S.E.M and the number of animals used is indicated by $n$. Antagonist potencies were expressed as $\mathrm{pEC}_{50}$ values (negative logarithm to base 10 of the molar concentration of the agonist producing $50 \%$ of the maximum response). Maximal responses were expressed as $\mathrm{E}_{\max }$ values (percentage of the maximum contractile response to $\mathrm{KCl}$ ). Multiple comparisons between treatment groups were performed using the analysis of variance (ANOVA) followed by a Tukey's test. All other statistical evaluations were carried out using Student's t-test (unpaired for comparison of means between independent experiments, paired for comparison of means between experiment and control) after checking the homogeneity of the variances by Ftest. $\mathrm{P}$ values $<0.05$ were considered to be significant. 
Am. J. Applied Sci., 8 (4): 303-309, 2011

\section{RESULTS}

Identifacation and charterization of synthesized compounds: The following are the properties and charterization of synthesized compounds.

N-(4-bromophenyl)-2-(3-nitrobenzylidene)-3-oxobutanamide c1: Yield: $53 \%$, m.p.: $115-116{ }^{\circ} \mathrm{C}$; Anal. Calcd. For $\mathrm{C}_{17} \mathrm{H}_{13} \mathrm{~N}_{2} \mathrm{O}_{4} \mathrm{Br}$ : C, 52.46; H, 3.37; N, 7.20. Found: C, 52.05; H, 3.43; N, 7.48.

N-(4-bromophenyl)-2-(3-chlorobenzylidene)-3-oxobutanamide c2: Yield: $55 \%$, m.p.: $119-120{ }^{\circ} \mathrm{C}$; Anal. Calcd. For $\mathrm{C}_{17} \mathrm{H}_{13} \mathrm{~N}_{2} \mathrm{O}_{4} \mathrm{Cl}$ : C, 53.92; H, 3.46; N, 3.70 . Found: C, 53.51; H, 3.67; N, 3.28.

2-(3-chlorobenzylidene)-N-(2, 6-dichlorophenyl)-3oxo-butanamide c3: Yield: $47 \%$, m.p.: $113-114{ }^{\circ} \mathrm{C}$; Anal. Calcd. For $\mathrm{C}_{17} \mathrm{H}_{12} \mathrm{NO}_{2} \mathrm{Cl}_{3}: \mathrm{C}, 55.39 ; \mathrm{H}, 3.24 ; \mathrm{N}$, 3.80. Found: C, 54.91; H, 3.28; N, 3.49.

2-(3-chlorobenzylidene)-N-(2, 6-dimethylphenyl)-3oxo-butanamide c4: Yield: $49 \%$, m.p.: $118-119{ }^{\circ} \mathrm{C}$; Anal. Calcd. For $\mathrm{C}_{19} \mathrm{H}_{18} \mathrm{NO}_{2} \mathrm{Cl}$ : C, 69.62; H, 5.53; N, 4.27. Found: C, 69.23; H, 5.57; N, 3.99.

N-(2,6-dimethylphenyl)-2-(3-nitrobenzylidene)- -3oxo-butanamide c5: Yield: $54 \%$, m.p.: $110-111{ }^{\circ} \mathrm{C}$; Anal. Calcd. For $\mathrm{C}_{19} \mathrm{H}_{18} \mathrm{~N}_{2} \mathrm{O}_{4}$ : C, 67.44; H, 5.36; N, 8.28. Found: C, $67.75 ; \mathrm{H}, 5.58 ; \mathrm{N}, 8$.

N-(2,6-dichlorophenyl)-2-(3-nitrobenzylidene)- -3oxo-butanamide c6: Yield: $56 \%$, m.p.: $121-122{ }^{\circ} \mathrm{C}$; Anal. Calcd. For $\mathrm{C}_{17} \mathrm{H}_{12} \mathrm{~N}_{2} \mathrm{O}_{4} \mathrm{Cl}_{2}$ : C, 53.85; H, 3.19; N, 7.39. Found: C, 53.84; $\mathrm{H}, 4.03 ; \mathrm{N}, 7.07$.

Methyl 5-(4-bromophenylcarbamoyl)-2,6-dimethyl4(3-nitrophenyl)-1,4-dihydropyridine-3-carboxylate 1: IR (KBr): $v\left(\mathrm{~cm}^{-1}\right) 3348$ (NH pyridine), $1700(\mathrm{C}=\mathrm{O}$ ester), $1680(\mathrm{C}=\mathrm{O}$ amide $) ;{ }^{1} \mathrm{H}$ NMR $\left(\mathrm{CDCl}_{3}\right): \delta \mathrm{ppm}=$ $8.18(\mathrm{t}, \mathrm{J}=1.90 \mathrm{~Hz}, 1 \mathrm{H}), 8.11-8.06(\mathrm{~m}, 1 \mathrm{H}), 7.74-7.67$ $(\mathrm{m}, 1 \mathrm{H}), 7.48(\mathrm{t}, \mathrm{J}=7.80,1 \mathrm{H}), 7.40-7.34(\mathrm{~m}, 2 \mathrm{H}), 7.27-$ 7.20 (m, 2H), 7.04 (bs, 1H, amide), 5.74 (bs, 1H), 5.01 (s, $\left.1 \mathrm{H}, \mathrm{H}_{4}\right), 3.68\left(\mathrm{~s}, 3 \mathrm{H}, \mathrm{OCH}_{3}\right), 2.35\left(\mathrm{~s}, 3 \mathrm{H}, \mathrm{CH}_{3}\right), 2.34$ (s, 3H, $\mathrm{CH}_{3}$ ); MS: m/z (\%) 486 (M+, 44), 456 (100), 425 (22), 299 (10); Anal. Calcd. For $\mathrm{C}_{22} \mathrm{H}_{20} \mathrm{BrN}_{3} \mathrm{O}_{5}$ : C, 54.33; $\mathrm{H}, 4.15$; N, 8.64. Found: C, 53.84; H, 4.03; N, 8.58.

Methyl 5-(4-bromophenylcarbamoyl)-4-(3chlorophenyl)-2,6-dimethyl-1,4-dihydropyridine-3carboxylate 2: IR ( $\mathrm{KBr}): v\left(\mathrm{~cm}^{-1}\right) 3312$ (NH pyridine), $1679 \quad(\mathrm{C}=\mathrm{O}$ ester $), 1614 \quad\left(\mathrm{C}=\mathrm{O}\right.$ amide); ${ }^{1} \mathrm{H}$ NMR $(\mathrm{CDCl}): \delta \mathrm{ppm}=7.38-7.16(\mathrm{~m}, 8 \mathrm{H}$, aromatic), $7.04(\mathrm{bs}$,
$1 \mathrm{H}$, amide), $5.68(\mathrm{bs}, 1 \mathrm{H}), 4.81\left(\mathrm{~s}, 1 \mathrm{H}, \mathrm{H}_{4}\right), 4.78(\mathrm{~s}, 1 \mathrm{H}$, $\left.\mathrm{H}_{4}\right), 3.68\left(\mathrm{~s}, 3 \mathrm{H}, \mathrm{OCH}_{3}\right), 2.35\left(\mathrm{~s}, 3 \mathrm{H}, \mathrm{CH}_{3}\right), 2.34(\mathrm{~s}, 3 \mathrm{H}$, $\mathrm{CH}_{3}$ ); MS: m/z (\%) 475 (M+, 97), 472 (17), 397 (15); Anal. Calcd. For $\mathrm{C}_{22} \mathrm{H}_{20} \mathrm{BrClN}_{2} \mathrm{O}_{3} \cdot 0.25 \mathrm{H}_{2} \mathrm{O}$ : C, 55.17; H, 4.28; N, 5.85. Found: C, 55.03; H, 4.73; N, 5.50.

Methy

4-(3-chlorophenyl)-5-(2,6dichlorophenylcarbamoyl)-2,6-dimethyl-1,4-

dihydropyridine-3-carboxylate 3: IR $(\mathrm{KBr}): v\left(\mathrm{~cm}^{-1}\right)$ $3250(\mathrm{NH}$ pyridine $), 1660(\mathrm{C}=\mathrm{O}$ ester $), 1608(\mathrm{C}=\mathrm{O}$ amide); ${ }^{1} \mathrm{H}$ NMR $\left(\mathrm{CDCl}_{3}\right): \delta \mathrm{ppm}=7.41-7.16(\mathrm{~m}, 7 \mathrm{H}$, aromatic), $6.88(\mathrm{bs}, 1 \mathrm{H}$, amide), $5.68(\mathrm{bs}, 1 \mathrm{H}), 5.01(\mathrm{~s}$, $\left.1 \mathrm{H}, \mathrm{H}_{4}\right), 3.07\left(\mathrm{~s}, 3 \mathrm{H}, \mathrm{OCH}_{3}\right), 2.41\left(\mathrm{~s}, 3 \mathrm{H}, \mathrm{CH}_{3}\right), 2.36$ (s, $\left.3 \mathrm{H}, \mathrm{CH}_{3}\right) ; \mathrm{MS}: \mathrm{m} / \mathrm{z}(\%) 465\left(\mathrm{M}^{+}, 100\right), 431$ (12); Anal. Calcd. For $\mathrm{C}_{22} \mathrm{H}_{19} \mathrm{Cl}_{3} \mathrm{~N}_{2} \mathrm{O}_{3}: \mathrm{C}, 56.73 ; \mathrm{H}, 4.11 ; \mathrm{N}, 6.01$. Found: C, 56.74; H, 4.12; N, 5.91.

Methyl 4-(3-chlorophenyl)-5-(2,6-

dimethylphenylcarbamoyl)-2,6-dimethyl-1,4dihydropyridine-3-carboxylate 4: IR $(\mathrm{KBr}): v\left(\mathrm{~cm}^{-1}\right)$ 3267 ( NH pyridine), $1684(\mathrm{C}=\mathrm{O}$ ester $), 1645(\mathrm{C}=\mathrm{O}$ amide); ${ }^{1} \mathrm{H}$ NMR $\left(\mathrm{CDCl}_{3}\right): \delta \mathrm{ppm}=7.39-7.01(\mathrm{~m}, 7 \mathrm{H}$, aromatic), 6.51 (bs, 1H, amide), $5.69(\mathrm{bs}, 1 \mathrm{H}), 4.91(\mathrm{~s}$, $\left.1 \mathrm{H}, \mathrm{H}_{4}\right), 3.68\left(\mathrm{~s}, 3 \mathrm{H}, \mathrm{OCH}_{3}\right), 2.39\left(\mathrm{~s}, 3 \mathrm{H}, \mathrm{CH}_{3}\right.$ pyridine), $2.37\left(\mathrm{~s}, 3 \mathrm{H}, \mathrm{CH}_{3}\right.$ pyridine $), 1.93\left(\mathrm{~s}, 3 \mathrm{H}, \mathrm{CH}_{3}\right.$ phenylcarbamoyl), $1.59\left(\mathrm{~s}, 3 \mathrm{H}, \mathrm{CH}_{3}\right.$ phenylcarbamoyl); MS: m/z (\%) $425\left(\mathrm{M}^{+}, 100\right), 423$ (6); Anal. Calcd. For $\mathrm{C}_{24} \mathrm{H}_{25} \mathrm{ClN}_{2} \mathrm{O}_{3}$ : C, 67.84; H, 5.93; N, 6.59. Found: C, $67.95 ; \mathrm{H}, 6.21 ; \mathrm{N}, 6.31$.

Methyl 5-(2,6-dimethylphenylcarbamoyl)-2,6dimethyl-4-(3-nitrophenyl)-1,4-dihydropyridine-3-

carboxylate 5: IR ( $\mathrm{KBr}): v\left(\mathrm{~cm}^{-1}\right) 3272(\mathrm{NH}$ pyridine), $1685(\mathrm{C}=\mathrm{O}$ ester $), 1606 \quad(\mathrm{C}=\mathrm{O}$ amide $) ;{ }^{1} \mathrm{H}$ NMR $\left(\mathrm{CDCl}_{3}\right): \delta \mathrm{ppm}=8.24(\mathrm{t}, \mathrm{J}=1.92 \mathrm{~Hz}, 1 \mathrm{H}), 8.11-8.05$ $(\mathrm{m}, 1 \mathrm{H}), 7.81-7.70(\mathrm{~d}, \mathrm{~J}=9.68 \mathrm{~Hz}, 1 \mathrm{H}), 7.46(\mathrm{t}, \mathrm{J}=$ $7.96 \mathrm{~Hz}, 1 \mathrm{H}), 7.11-6.97$ (m, 3H), 6.54 (bs, 1H, amide), 5.75 (bs, 1H), $5.12(\mathrm{~s}, 1 \mathrm{H}, \mathrm{H} 4), 3.69\left(\mathrm{~s}, 3 \mathrm{H}, \mathrm{OCH}_{3}\right)$, 2.39 (s, $3 \mathrm{H}, \mathrm{CH}_{3}$ pyridine), 2.34 (s, $3 \mathrm{H}, \mathrm{CH}_{3}$ pyridine), $1.93\left(\mathrm{~s}, 3 \mathrm{H}, \mathrm{CH}_{3}\right.$ phenylcarbamoyl), $1.59\left(\mathrm{~s}, 3 \mathrm{H}, \mathrm{CH}_{3}\right.$ phenylcarbamoyl); MS: m/z (100\%) 34 (M-, 100), 311 (46); Anal. Calcd. For $\mathrm{C}_{24} \mathrm{H}_{25} \mathrm{~N}_{3} \mathrm{O}_{5}$ : C, 66.19; H, 5.79; N, 9.65. Found: C, 66.18; H, 6.13; N, 9.20.

Methyl 5-(2,6-dichlorophenylcarbamoyl)-2,6dimethyl-4-(3-nitrophenyl)- 1,4-dihydropyridine-3carboxylate 6: $\mathrm{IR}(\mathrm{KBr}): v\left(\mathrm{~cm}^{-1}\right) 3261$ (NH pyridine), $1696 \quad(\mathrm{C}=\mathrm{O}$ ester $), 1610 \quad(\mathrm{C}=\mathrm{O}$ amide $) ;{ }^{1} \mathrm{H}$ NMR $\left(\mathrm{CDCl}_{3}\right): \delta=\operatorname{ppm} 8.23(\mathrm{t}, J=1.92 \mathrm{~Hz}, 1 \mathrm{H}), 8.10-8.05$ $(\mathrm{m}, 1 \mathrm{H}), 7.78-7.72(\mathrm{~m}, 1 \mathrm{H}), 7.50-7.42(\mathrm{~m}, 1 \mathrm{H}), 7.31-$ $7.25(\mathrm{~m}, 3 \mathrm{H}), 6.79(\mathrm{bs}, 1 \mathrm{H}$, amide), $5.79(\mathrm{bs}, 1 \mathrm{H}), 5.14$ (s, $\left.1 \mathrm{H}, \mathrm{H}_{4}\right), 3.69\left(\mathrm{~s}, 3 \mathrm{H}, \mathrm{OCH}_{3}\right), 2.39\left(\mathrm{~s}, 3 \mathrm{H}, \mathrm{CH}_{3}\right), 2.35$ (s, 3H, $\mathrm{CH}_{3}$ ); MS: m/z (\%) $474\left(\mathrm{M}^{-}, 100\right), 350$ (8); Anal. Calcd. For $\mathrm{C}_{22} \mathrm{H}_{19} \mathrm{Cl}_{2} \mathrm{~N}_{2} \mathrm{O}_{5}$ : C, 55.48; H, 4.02; N, 8.82. Found: C, 55.44; H, 4.21; N, 8.70. 
Pharmacological activity: The calcium channel blocking (CCBA) of 1, 4-DHP derivatives 1-6 was determined using PCASM assay (Moritz et al., 2006). The CCBA results of tested compounds are shown in Table 2 .

\section{DISCUSSION}

Properties of synthesized compound: The prepared compounds are white or light yellow crystalline solids, soluble at room temperature in acetone and chloroform, by heating in lower alcohols, benzene, toluene and xylene and insoluble in water. The structure, molecular formulae, molecular weights, melting points and yields of the new 5-phenylcarbamoly derivatives are presented in Table 1, the results shows that the molecular weight of the prepared compounds were ranged between 424.91 - 476.30, the melting points between $108-251^{\circ} \mathrm{C}$ and a good yield of synthesized compounds was obtained which ranges between 53.7-75.3\%.

Pharmacological activity: Whereas compounds 1-2 failed to show any blocking activity in the PCASM assay, the compounds 3-6 were found to be active in different degrees in Table 2 . The results observed indicated that both compounds 5 and 6 were the most active, as compound 5 and 6 showed a calcium channel blocking potency of $6.46 \pm 0.07$ and $6.35 \pm 0.10$ respectively. The observed antagonistic results for 5 and 6 are comparable with the standard calcium channel blocker verapamil which exhibited a blocking potency of $6.97 \pm 0.15$ and the potency of m-nifedipine (7.48 \pm 0.05$)$ (Moritz et al., 2006) was not achieved. On the other hand, the maximal antagonistic effect, expressed as a percentage $E_{\max }$ value, of $106 \pm 5$ observed by verapamil and of $101 \pm 1$ by m-nifedipine was not achieved by all derivatives, since the highest $E_{\max }$ results was found by $99 \pm 1$, observed for both compounds 3 and 5. The obtained results indicate that the calcium channel blocking activity of m-nifedipine maintains, even by substituting an ester moiety with an aromatic substituted amide moiety at C5-position. Furthermore, structure-activity relationships observed in the present study underline the important impact of the presence of 2,6-dimethyl-or 2,6-dichloro-substituents at phenyl ring of 5-phenylcarbamoyl moiety, since absence of both substituents or shifting of one substituent into 4-position led to completely inactive compounds. The calcium channel blocking activity results for the compounds 1 and 2 supported this hypothesis, where presence of brom at 4-position led to derivatives which failed to exhibit any blocking activity at porcine coronary artery smooth muscles, even with presence of a 3'-chloro (or 3'-nitro)phenyl substitute on 1,4-DHP ring. Moreover, it has been observed that a 3 -position of nitro-or chlor group necessitates the presence of a 2, 6-dimethyl- or 2, 6-dichloro substituents on the 5-phenyl carbamoyl moiety.

Table 1: Characteristics of the new compounds

\begin{tabular}{|c|c|c|c|c|c|}
\hline $\mathrm{R}^{1}$ & $\mathrm{R}^{2}$ & Molecular Formula & Molecular Weight & Melting Point $\left({ }^{\circ} \mathrm{C}\right)$ & Yield (\%) \\
\hline $\mathrm{NO}_{2}$ & & $\mathrm{C}_{22} \mathrm{H}_{20} \mathrm{~N}_{3} \mathrm{O}_{5} \mathrm{Br}$ & 426.25 & $217-219$ & 63.6 \\
\hline $\mathrm{Cl}$ & & $\mathrm{C}_{22} \mathrm{H}_{20} \mathrm{~N}_{2} \mathrm{O}_{3} \mathrm{BrCl}$ & 475.71 & 108-109 & 68.8 \\
\hline $\mathrm{Cl}$ & & $\mathrm{C}_{22} \mathrm{H}_{19} \mathrm{~N}_{2} \mathrm{O}_{3} \mathrm{Cl}_{3}$ & 465.76 & $250-251$ & 73.3 \\
\hline $\mathrm{Cl}$ & $\begin{array}{l}\mathrm{H}_{3} \mathrm{C} \\
\mathrm{H}_{3} \mathrm{C}\end{array}$ & $\mathrm{C}_{24} \mathrm{H}_{25} \mathrm{~N}_{2} \mathrm{O}_{3} \mathrm{Cl}$ & 424.91 & $230-231$ & 53.7 \\
\hline $\mathrm{NO}_{2}$ & $\mathrm{H}$ & $\mathrm{C}_{24} \mathrm{H}_{25} \mathrm{~N}_{3} \mathrm{O}_{5}$ & 425.38 & $213-214$ & 55.5 \\
\hline $\mathrm{NO}_{2}$ & 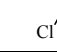 & $\mathrm{C}_{22} \mathrm{H}_{19} \mathrm{~N}_{3} \mathrm{O}_{5} \mathrm{Cl}_{2}$ & 476.30 & $233-234$ & 75.3 \\
\hline
\end{tabular}


Am. J. Applied Sci., 8 (4): 303-309, 2011

Table 2: Observed calcium channel blocking activities for compounds 1-6

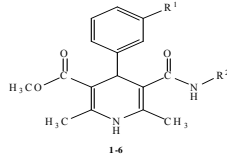

\begin{tabular}{llllll} 
& & & $\mathrm{pEC}$ & & $\mathrm{E}_{\max }(\%)$ \\
No. & $\mathrm{R}^{1}$ & $\mathrm{R}^{2}$ & $\pm \mathrm{SEM}$ & $\pm \mathrm{SEM}$ & $\mathrm{n}$ \\
\hline 1 & $\mathrm{NO}_{2}$ & 4-bromophenyl & no effect & - & 3 \\
2 & $\mathrm{Cl}$ & 4-bromophenyl & no effect & - & 4 \\
3 & $\mathrm{Cl}$ & 2, 6-dichlorophenyl & $4.37 \pm 0.10$ & $99 \pm 1$ & 5 \\
4 & $\mathrm{Cl}$ & 2, 6-dimethylphenyl & $5.37 \pm 0.10$ & $92 \pm 7$ & 3 \\
5 & $\mathrm{NO}_{2}$ & 2, 6-dimethylphenyl & $6.46 \pm 0.07$ & $99 \pm 1$ & 5 \\
6 & $\mathrm{NO}_{2}$ & 2, 6-dichlorophenyl & $6.35 \pm 0.10$ & $92 \pm 7$ & 4 \\
Verapamil & - & - & $6.97 \pm 0.15$ & $106 \pm 5$ & 5 \\
m-Nifedipine & & & $7.48 \pm 0.05^{*}$ & $101 \pm 1^{*}$ & - \\
\hline
\end{tabular}

*(Moritz et al., 2006)

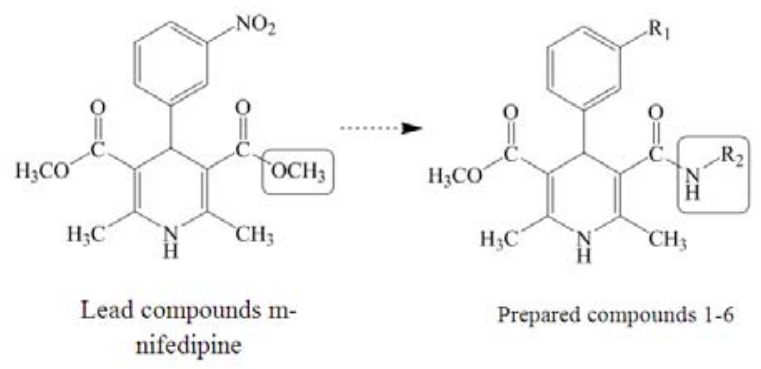

Fig. 4: Lead compound m-Nifedipine and general structure of developed and studied compounds 1-6

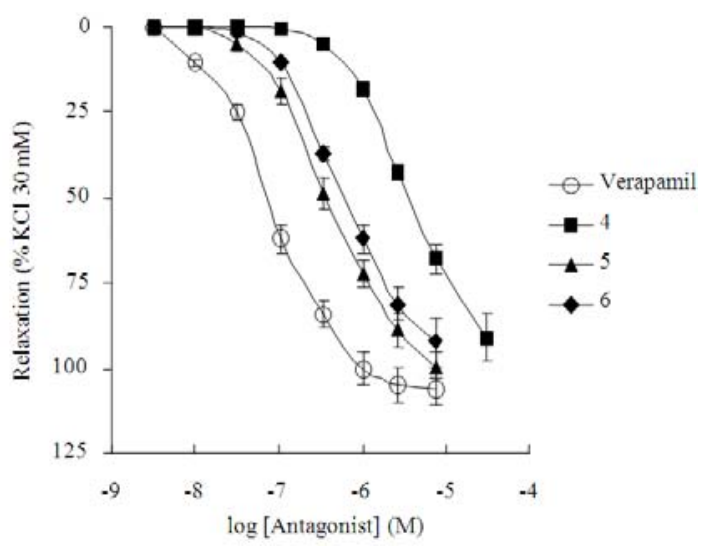

Fig. 5: Cumulative concentration-response curves to verapamil and selected 5-phenylcarbamoyl derivatives 4-6

The combination of such substitutes was realized in compound 5 and 6 which were found to exhibit the highest calcium channel blocking potency $(6.46 \pm 0.07)$ and $(6.35 \pm 0.10)$, respectively.
Since compounds 4-6 were moderate to high potent in relaxing porcine coronary arteries, a cumulative concentration-response curves to both compounds was established to further investigate whether a competitive antagonism is present or not. The antagonist potencies and maximal responses are summarized in Table 2 . The effects were not different in tissues with endothelium compared to those without endothelium. The most potent vasodilator was compound 5 which showed a vasodilator effect similar to that of verapamil, the standard antagonist of test model used in the present study (Fig. 4 and 5).

Vasodilator effects to compounds 4-6 were not inhibited by the estrogen receptor antagonist ICI $182,780(10 \mu \mathrm{M})$, neither in endothelium-intact nor in endothelium-denuded arterial rings (not shown), indicating that relaxation effects were observed only through a competitive antagonistic interaction of tested compounds with calcium channels of porcine coronary artery smooth muscles.

\section{CONCLUSION}

The obtained results reveal that a modification of an ester moiety in m-nifedipine through a replacement with an aromatic substituted amide led to a new class of 5-phenylcarbamoyl derivatives of 1, 4-DHPs with calcium channel blocking activity in porcine coronary arteries. Although some of the developed compounds possess maximal effects comparable to m-nifedipine. Since amides are known to be more resistant to metabolizing enzymes than their corresponding esters, the developed compounds in the present study will predicatively show an increased metabolic stability and consequently longer duration of actions compared to mnifedipine and could be, therefore, suitable candidates for further optimization to be evaluated as a new class of antihypertensive drugs.

On the other hand and due to their expected higher lipophilic character, continuous research efforts are required to investigate their cardiovascular profile. Furthermore, additional modifications of the titled compounds are needed to allow pharmacological investigations of their effects in the central nervous system, e.g., cognitive disorders, as there are considerable evidences that calcium is an important factor for the induction of epilepsy and calcium channel blockers, especially of 1,4-DHP with high lipophilic character, proved to be effective against the whole range of convulsive procedures including electro and Pentylenetetrazole (PTZ) convulsions (Ghasemi et al., 2010; Shafiee et al., 2004). The latter pharmacological investigations are required to prove the potential of 
titled compounds as an adjuvant, non-sedative antiepileptic drugs, especially in those patients in whom conventional therapy has been inadequate or in patients who are refractory to anticonvulsant treatment, or in cases of untreatable epilepsy.

\section{ACKNOWLEDGEMENT}

The researchers are thankful to Professor Heinz $\mathrm{H}$. Pertz, Institute of Biology at Free University of Berlin, Germany for his kind help in the pharmacological testing of titled compounds.

\section{REFERENCES}

Beig, M.I., R. Chandra, A. Talwar, M. Fahim and A. Katyal, 2009. Epileptic seizure-induced hypertension and its prevention by calcium channel blockers: a real-time study in conscious telemetered rats. Can. J. Physiol. Pharmmacol., 87: 572-580. PMID: 19767881

Cheung, L.L.W., S.A. Styler and A.P. Dicks, 2010. Rapid and convenient synthesis of the 1,4dihydropyridine privileged structure. J. Chem. Edu., 87: 628-630. DOI: 10.1021/ed100171g

Ghasemi, M., H. Shafaroodi, S. Nazarbeiki, H. Meskar and P. Heydarpour et al., 2010. Voltage-dependent calcium channel and NMDA receptor antagonists augment anticonvulsant effects of lithium chloride on pentylenetetrazole-induced clonic seizures in mice. Epilepsy Behav., 18: 171-178. DOI: 10.1016/j.yebeh.2010.04.002

Khoshneviszadeh, M., N. Edraki, J. Katayoun, A. Alborzi and B. Pourabbas, 2009. Synthesis and biological evaluation of some new 1,4dihydropyridines containing different ester substitute and diethyl carbamoyl group as antitubercular agents. Bioorgan. Med. Chem., 17: 1579-1586. DOI: 10.1016/j.bmc.2008.12.070

Luszczki, J.J., M.K. Trojnar, M.P. Trojnar, Z. KimberTrojnar and B. Szostakiewicz et al., 2008. Effects of amlodipine, diltiazem, and verapamil on the anticonvulsant action of topiramate against maximal electroshock-induced seizures in mice. Can. J. Physiol. Pharm., 86: 113-121. DOI: 10.1139/Y08-007
Miri, R., K. Javidnia, B. Hemmateene, M. Tabarzad and M. Jafarpour, 2009. Synthesis, evaluation of pharmacological activities and quantitative structure-activity relationship studies of a novel group of bis(4-nitroaryl-1,4-dihyropyridine). Chem. Biol. Drug Des., 73: 225-235. DOI: $10.1111 /$ j.1747-0285.2008.00770.x

Moritz, A., O.A. Radtke, R. Gust, E. Glusa and H.H. Pertz, 2006. Characterisation of the relaxant response to raloxifene in porcine coronary arteries. Eur. J. Pharmacol., 545: 153-160. DOI: 10.1016/j.ejphar.2006.06.049

NGouemo, P., R. Yasuda and C.L. Faingold, 2010. Seizure susceptibility is associated with altered protein expression of voltage-gated calcium channel subunits in inferior colliculus neurons of the genetically epilepsy-prone rat. Brain Res., 1308: 153-157. DOI: 10.1016/j.brainres.2009.10.019

Otoom, S. and Z. Hasan, 2006. Nifedipine inhibits picrotoxin-induced seizure activity: further evidence on the involvement of L-type calcium channel blockers in epilepsy. Fundam. Clin. Pharmol., 20: 115-119. DOI: 10.1111/j.14728206.2006.00393.x

Poole-Wilson, P.A., B.A. Kirwan, Z. Voko, S. de Brouwer and F.J. van Dalen et al., 2006. Safety of nifedipine GITS in stable angina: The action trial. Cardiovasc. Drugs Ther., 20: 45-54. DOI: 10.1007/s10557-006-6312-4

Richard, S., 2005. Vascular effects of calcium channel antagonists: new evidence. Drugs, 65: 1-10. PMID: 16398057

Samzadeh-Kermani, A., H. Shafaroodi, R. Miri, H. Mirkhani and M. Vosooghi et al., 2009. Lipophilic 2-(4-chlorophenyl)-4-thiazolyl-1,4dihydropyridines: synthesis, calcium channel antagonist activity, and protection against pentylenetetrazole-induced seizure. Med. Chem. Res., 18: 112-126. DOI: 10.1007/s00044-0089112-5

Shafiee, A., N. Rastkari and M. Sharifzadeh, 2004. Anticonvulsant activities of new 1,4dihydropyridine derivatives containing 4nitroimidazolyl substituents. DARU J. Pharmace. Sci., 12: 81-86. 